\title{
Understanding customer-centric socialization in tourism services
}

\author{
HsiuJu Rebecca Yen ${ }^{1} \cdot$ Hoa Pham Thi ${ }^{1}$ Eldon Y. $\mathrm{Li}^{2,3}$
}

Received: 2 June 2021 / Accepted: 13 October 2021 / Published online: 26 October 2021

(c) The Author(s), under exclusive licence to Springer-Verlag GmbH Germany, part of Springer Nature 2021

\begin{abstract}
Co-creating value with customers has been a strategic focus for tourism companies. Grounded on the organizational socialization theory, this study examines a framework of customer-centric socialization process for tourism providers and how it affects tourists' co-creation readiness $(C C R)$ and co-creation behavior $(C C B)$. Through 227 tourists' responses, the study confirms that tourist education positively influences tourists' CCB, and CCR partially mediates this effect. Furthermore, the individual difference in personal involvement significantly moderates this mediated relationship, wherein high-involvement tourists exhibit lower CCR than lowinvolvement tourists when tourist-education quality is low. The study concludes that tourist education is the key to promoting tourists' CCR and CCB and completing the customer-centric socialization process in tourism.
\end{abstract}

Keywords Co-creation behavior · Role readiness · Tourist education · Tourism involvement . Customer-centric socialization

Eldon Y. Li

eli@calpoly.edu

HsiuJu Rebecca Yen

hjyen@mx.nthu.edu.tw

Hoa Pham Thi

hoaphamthi@iss.nthu.edu.tw

1 Institute of Service Science, National Tsing Hua University, 101, Sec. 2, Kuang-Fu Road, Hsinchu 300044, Taiwan, ROC

2 College of Management, National Chung Cheng University, 168, Sec.1, University Rd., Minghsiung, Chiayi 621301, Taiwan, ROC

3 School of Economics and Management, Tongji University, 1500, Siping Road, Shanghai 200092, China 


\section{Introduction}

Owing to the outbreak of COVID-19 in 2020, many countries have imposed travel restrictions, and people have been reluctant to travel for fear of infection. The International Air Transport Association (IATA) reports that global passenger traffic will not return to pre-COVID-19 levels until 2024 (IATA 2020). This crisis has globally caused the tourism industry heavy income losses (Crossley 2020; UNWTO 2020). Many governments worldwide have tried to revitalize tourism while controlling the negative effects of coronavirus on tourists' safety and well-being. The governments created travel bubbles or green corridors, requiring nucleic acid tests before departure and after arrival, a shortened quarantine period, and limited travel without quarantine (Lall 2020).

Before the COVID-19 pandemic, customer value co-creation (VCC) is increasingly embraced by tourism providers and the customers in the tourism industry to derive values from the collaboration process (Su et al. 2016; Hong and Lee 2015; Im and Qu 2017; Campos et al. 2017). Today, under the pandemic, ensuring tourists' safety and well-being has become the utmost important concern for tourism providers and customers. As a result, tourism companies have adopted tourist VCC as a tourism recovery strategy to promote and sustain their services (Hoang et al. 2021; Persson-Fischer and Liu 2021; Sharma 2021). Therefore, a research model related to tourist co-creation behavior (CCB) is essential for the sustainable recovery of the tourism industry under risky pandemic conditions.

The CCB is crucial to the success of tourism offerings as it brings forth positive consequences in trip memorability (Campos et al. 2017), the performance of new travel products (Tseng and Chiang 2016), intention to revisit (Sugathan and Ranjan 2019), and community empowerment in sustainable tourism development (Hamilton and Alexander 2013). For example, Marriott's "Travel Brilliantly" program encourages customers to submit ideas via its online platform and vote for the best ideas and test them on selected customers and hotels to improve travelers' experiences in staying at the hotels. The program has brought Marriott more than just the ideas; it has been used as a marketing tool to re-establish Marriott as an innovative and modern company (LiekeDemmers 2016).

Tourism providers have increasing enthusiasm for CCB. The extant literature is abundant with empirical studies of behavioral consequences and antecedents (Grissemann and Stokburger-Sauer 2012; Prebensen et al. 2013; Cabiddu et al. 2013; Im and Qu 2017). However, little attention is directed toward the behavioral process. Empirically, prior studies revealed that company support for communicating with customers and fulfilling their needs could effectively engage customers in CCBs (Grissemann and Stokburger-Sauer 2012; Im and Qu 2017). However, company support is not enough to transform a tourist from bystanders into effective co-creators. As Lehrer et al. (2012) pointed out, co-creation greatly depends on providing clear instructions and working closely between the company and its customers. Büttgen et al. (2012) revealed that companies commonly undertake these practices to transform employee and customer behaviors during the organizational socialization process. They further emphasize the importance 
of service providers' proactive and repeated socialization activities. As such, the customer socialization process driving tourist $\mathrm{CCB}$ is an important issue to explore.

A scrutiny of the literature in customer socialization reveals that most companies consider customers partial employees (Guo et al. 2013). However, the process is company-driven, company-led, and company-centric and remains a co-production process instead of a co-creation process. Therefore, a movement to customer-driven, customer-led, and customer-centric socialization (CCS) is urgently needed to treat customers as partners and prepare them for co-creation. The CCS is significantly different than the traditional customer socialization in many aspects. Table 1 summarizes the differences between the three socialization processes. Finally, individual/personal differences can affect socialization outcomes, e.g., self-efficacy (Eden and Aviram 1993) and personality traits (Kammeyer-Mueller and Wanberg 2003). This study investigates whether this effect happens in the CCS process.

To address the aforementioned research gaps, this study proposes three stages of a CCS process adapted from organizational socialization theory (Van Maanen and Schein 1979), develops components of the corresponding stages, and identifies behaviors of the VCC concept. Specific research questions are as follows:

RQ1 What are the stages of the customer-centric socialization process?

RQ2 What are the components of each stage? Why are they chosen?

RQ3 What role does individual difference play in influencing this process for tourism?

RQ4 What are the dimensions that measure the tourist behavior of the value cocreation concept?

RQ5 How are the outcomes of stages interplay in this process?

The present research contributes to the tourism literature in five ways. First, it provides new insights into the VCC concept under the lens of organizational socialization theory (OST). Previous studies have used the VCC concept as a tourist's voluntary and active participation/interaction during a tour under the guidance of the tourism provider (Bertella 2014; Campos et al. 2015, 2016; Ihamäki 2012; Prebensen and Foss 2011; Tan et al. 2014). The current research extends this concept from organizational socialization into customer-centric socialization. The finding suggests that VCC cannot simply rely on tourists' voluntarily active participation to achieve its effectiveness; it needs standardized and personalized education from the tourism companies. Such education complements the company's support for co-creating value suggested by prior studies (Grissemann and Stokburger-Sauer 2012). Thus, this research enriches the theoretical perspective of the VCC concept. Second, most prior studies conceptualize VCC with a single dimension (e.g., Grissemann and Stokburger-Sauer 2012; Campos et al. 2017). It is insufficient to reflect the concept's holistic scope and process (Payne et al. 2008; Jaakkola et al. 2015). To overcome this weakness, this study adopts three dimensions of post-sales services (Challagalla et al. 2009) to conceptualize the 


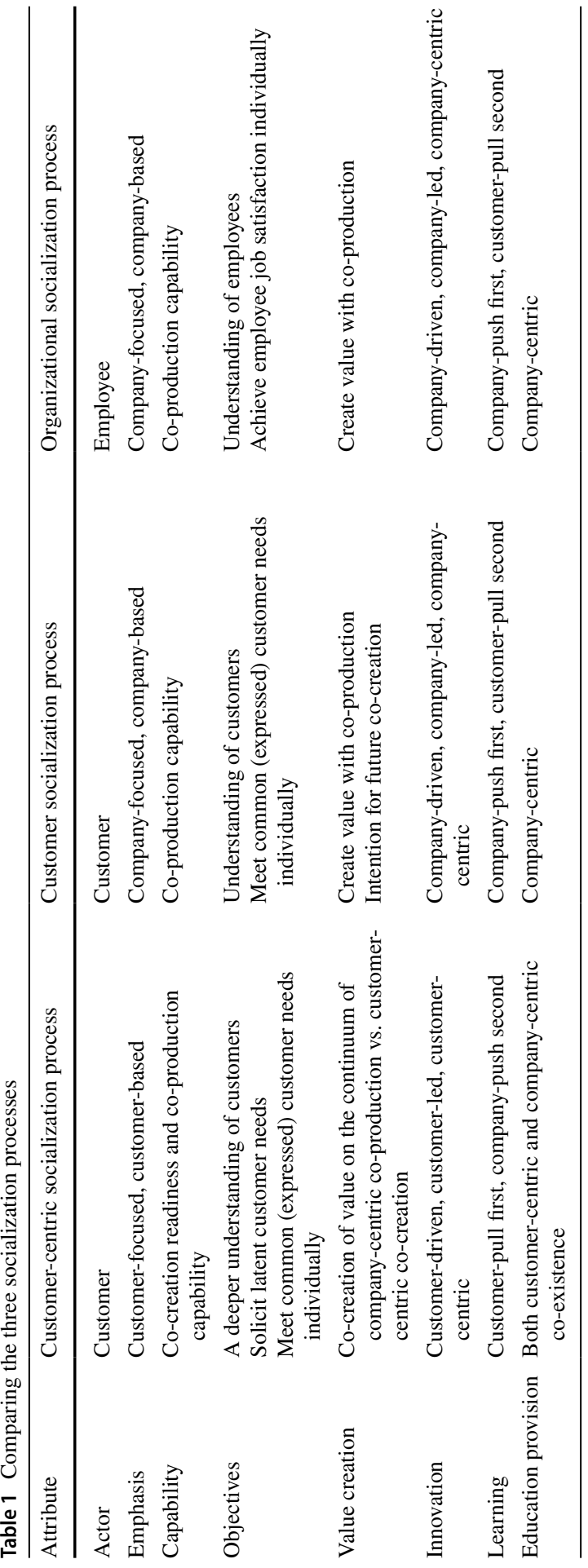


VCC behaviors in the tourism context. Third, the current study identifies the moderating role of personal involvement in VCC, revealing that VCC may not happen unless customers are knowledgeable about tourism and appreciate the co-creation experience. This finding is consistent with the prior studies (Yim et al. 2012) that VCC is affected by self-efficacy (i.e., confidence and perceived capability) in cocreation. Finally, this study proposes a VCC generation process by applying the lens of OST. This process is different from that of Im and Qu (2017), in which $\mathrm{VCC}$ is driven by the perceived physical environment and support for customers.

The remainder of this paper is organized as follows: First, Sect. 2 introduces the literature review and hypotheses development, followed by the research method in Sect. 3. Next, Sect. 4 describes analyses and results, while Sect. 5 presents conclusions, theoretical contributions, and practical implications. Finally, Sect. 6 discusses the research limitations and future research.

\section{Review of literature and hypotheses development}

\subsection{Organizational socialization theory (OST)}

This study applies the OST to tourism management and places tourists in individual socialization processes. Jones (1986) suggests that newcomers in a company usually experience a series of stages in the organizational socialization process. The stages in sequence are (1) shared understanding, (2) role orientation, and (3) role behavior. In the first stage of shared understanding, newcomers entering organizations must apply organizational socialization tactics to understand organizational reality (Van Maanen and Scbein 1979). These tactics can be classified into two types: institutionalized and individualized tactics. The collective-based institutionalized tactic guides new employees to gain common learning experiences structured by the organization and develop standardized responses to situations. In contrast, the personal-based individualized tactic provides newcomers with opportunities to develop distinctive responses (Van Maanen and Schein 1979).

At the second stage of role orientation, the newcomers adjust their roles in the organization. A role orientation is "the manner newcomers perform their roles and adjust to task requirements" (Jones 1986, p. 63). The institutionalized tactic produces custodial role-orientation, in which newcomers accept the status quo and produce standardized responses to situations. In contrast, the individualized tactic engenders heterogeneous innovative role-orientation. In this orientation, the newcomers proactively change the methods for performing their roles or missions and responds to situations heterogeneously (Jones 1986).

In the third stage of role behavior, the newcomers react to endogenous or exogenous conditions according to their role orientations (Jones 1986). Under custodial role orientation, the newcomers display normative behaviors conforming to the organizational norm. In contrast, the newcomers with innovative role orientation exhibit innovative behaviors such as proposing new methods in timetable planning, teaching others to avoid accidents, taking care of others' safety, and so forth. As one cannot adjust one's role and behavior overnight, the organizational socialization 


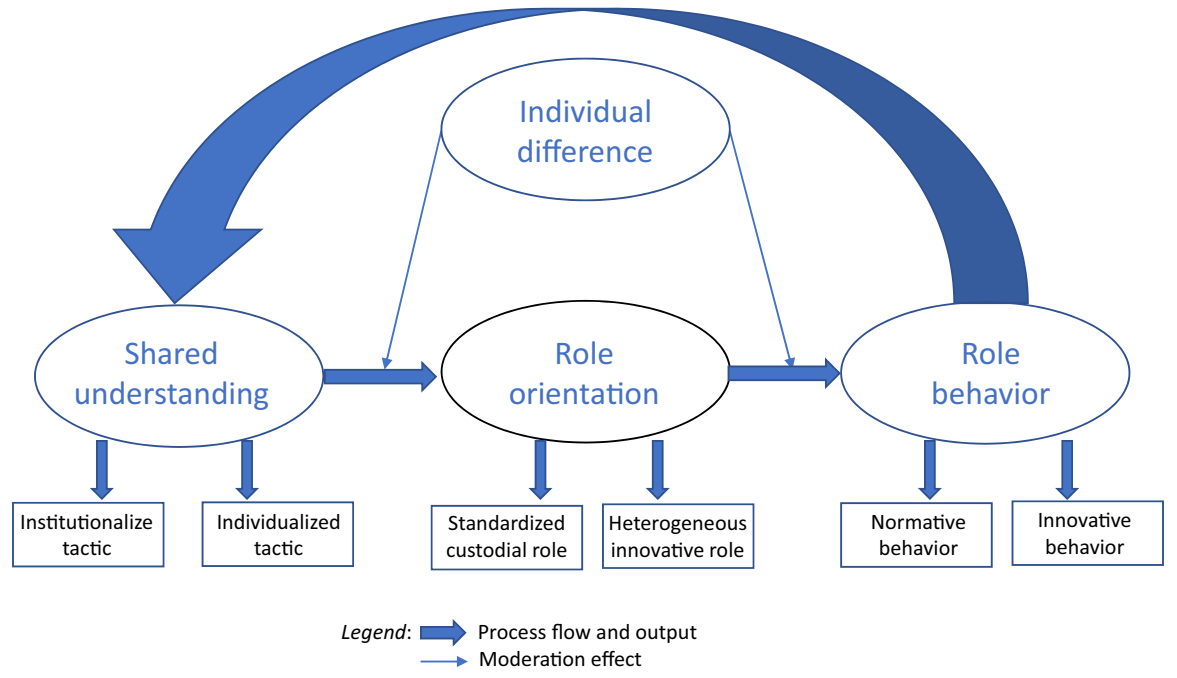

Fig. 1 The three-stage process cycle in organizational socialization theory

program must repeat the process entirely many times until it ultimately attains the goals. Finally, individual differences can affect organizational socialization outcomes and further moderate the effects of socialization tactics on individuals' role orientations and behaviors (Jones 1986). Figure 1 summarizes the cycle of the organizational socialization process in the OST, as discussed above.

\subsection{Co-existence of co-production and co-creation}

With the prevalence of service-dominant logic (SDL) today, business industries worldwide have been inculcated with the concepts of value-in-exchange, value-inuse (Vargo and Lusch 2004), and value-co-creation (Lusch and Vargo 2006). If a product is not consumed, its value is limited to the value-in-exchange during the bartering process. Co-production and co-creation are both essential activities in the customer value-creation process. While co-production activities are company-driven and passive, co-creation activities are customer-driven and active (Chathoth et al. 2013). Co-production characterizes a company-centric view of customer involvement and usage of customers' labor input to execute the process prescribed by the service firm (Payne et al. 2008). In contrast, co-creation refers to a high level of customer participation in the value-creation process by innovating, designing, and producing services with the firm before, during, and after the customers consume the services (Chathoth et al. 2013).

According to SDL, co-creation involves participation in the production of the core offering itself. It "can occur through shared inventiveness, co-design, or shared production of related goods, and can occur with customers and any other partners in the value network" (Lusch and Vargo 2006, p. 284). The co-creation process moves to a way of encouraging interaction through the encounter between the customer and 
the firm to address the customer's expressed and latent needs along the entire valuecreation process (Kristensson et al. 2008), away from the company-centric view of customer participation, as in co-production mode. The co-creation process emphasizes indulging in a dialogue with customers and using them as a resource to generate value-in-use (Chathoth et al. 2013). It allows the customers to tailor the services as they desire and enhance the end value of consumption. Based on the above discourse, co-production and co-creation should co-exist on a continuum (Chathoth et al. 2013). On one end, the company-driven co-production mode is passive, while on the other end, the customer-driven co-creation mode is active. The various services provided and the resources available to the service firm jointly determine the location of the customer's value-creation effort on this continuum.

\subsection{From organization socialization to customer-centric socialization}

\subsubsection{Organizational socialization and customer socialization}

Organizational socialization of customers (Kelley et al. 1990, p. 318) or customer socialization (Kelley et al. 1990, p. 319) increases as customers participate more actively in service provision, leading to customer participation and co-production (Kelley et al. 1992; Lengnick-Hall et al. 2000) and enhanced perceived service quality and customer satisfaction (Claycomb et al. 2001; Wu 2011; Guo et al. 2013). A customer's role as a partial employee in the co-production context is not as profound as a customer's role as a partner in the co-creation context. A scrutiny of the relevant literature reveals that customer socialization can help customers understand better their co-creation roles and perceive higher values for future CCBs. These consequently increase their intention for future co-creation (Dong et al. 2008).

\subsubsection{Customer-centric socialization}

Customer is the key actor in customer-centric socialization, as shown in Table 1, while customer socialization regards the company as the focal driver. As for the ability aspect, customers in customer-centric socialization are well-prepared and stay active in co-production and co-creation. In contrast, while in customer socialization, they are prepared for co-production only. When customers interact more actively with the company in customer-centric socialization than in customer socialization, understanding customers goes deeper and latent customers' needs get revealed better. As a result, value is created higher in customer-centric socialization since value creation is shifted toward co-creation along the co-production-co-creation continuum (Chathoth et al. 2013). As for innovation, customers are vital performers (instead of the company) who generate ideas and suggestions in the customerdriven socialization process. As for learning mode in customer-centric socialization, customers actively seek (pull) information from the company or other sources to fulfill their personal needs, followed by the company providing (push) information requested by the customers. Comparatively, in organizational or customer socialization, the company actively provides (push) information to customers to meet their 


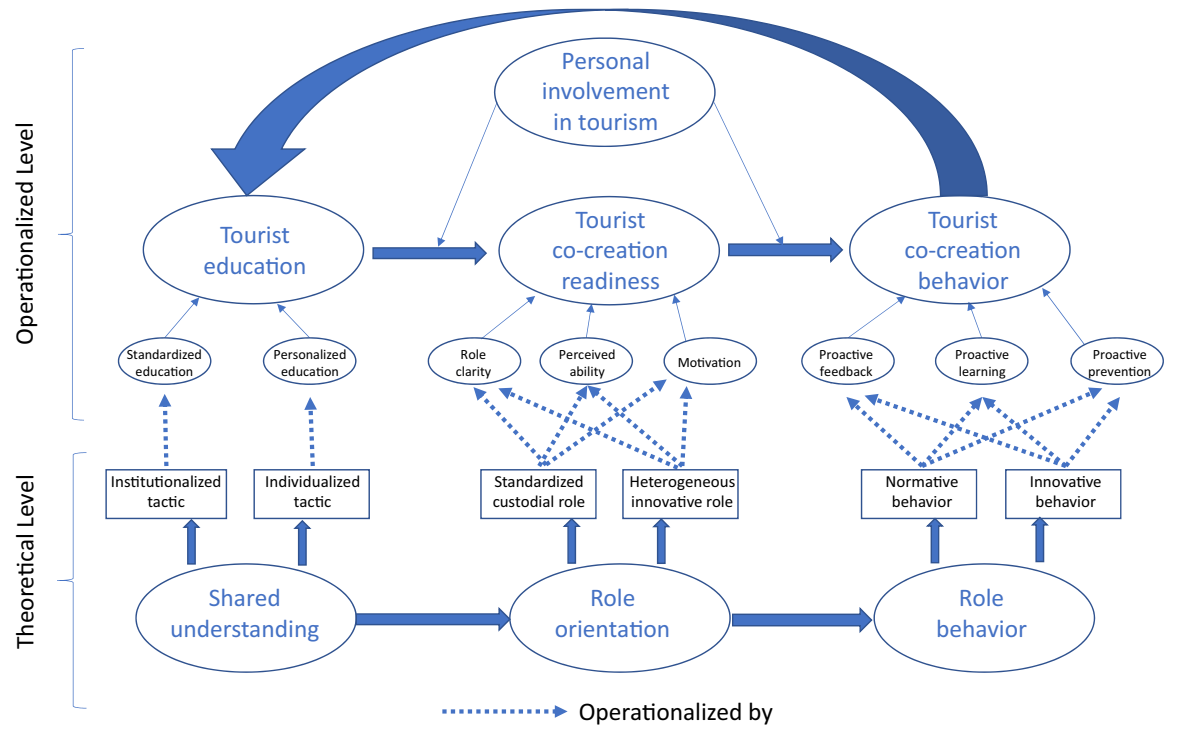

Fig. 2 Mapping the CCS process in tourism

common needs, followed by customers ask for (pull) information from the company for their special needs. Finally, for the education aspect, the CCS process empowers customers to take more active control over their educational program, while this program in the customer socialization process is controlled by the company (company-centric).

\subsection{Formalizing CCS process for tourism}

Based on the three-stage process cycle in Fig. 1, a customer-centric socialization model in tourism is proposed in Fig. 2, following the SDL. The model consists of three constructs mapping with the three stages in Fig. 1. The first construct is customer education in tourism, hereafter called tourist education, which maps with the shared-understanding stage in this three-stage process. This construct operationalizes the two types of tactics: institutionalized and individualized tactics. These tactics map with standardized education for all tourists' common needs in a group tour and personalized education for individual tourists' unique needs. The second construct, tourist's $C C B$, maps with the role-orientation stage; it consists of two orientations: custodial (standardized) and innovative (heterogeneous) roles. This construct operationalizes the role orientation with three dimensions: role clarity, perceived ability, and motivation. Each type of role orientation must encompass these three dimensions to achieve co-creation readiness (CCR). Role clarity refers to the extent to which tourists' knowledge and understanding of their roles in the tour (Meuter et al. 2005); perceived ability is the necessary knowledge, skills, and confidence required to perform role-related tasks (Meuter et al. 2005; Dong et al. 2015); and 
motivation refers to a desire to receive the rewards for performing the role-related tasks (Meuter et al. 2005; Dong et al. 2015). These three dimensions must work together to make tourists ready for roles-oriented co-creation. It is noteworthy that CCR is a proximal outcome of the socialization process.

Finally, the third construct of CCB maps with the role-behavior stage in the CCS process. The two types of role-behavior patterns (normative and innovative behaviors) are operationalized with the three behaviors adapted from Challagalla et al. (2009): proactive prevention of unexpected conditions, proactive learning of tourrelated knowledge, and proactive feedback of service quality. Tourists must display these normative and innovative behaviors to make the tour successful. Finally, the fourth construct of personal involvement in tourism indicates the tourist's passion for travel. It is an individual difference, similar to self-efficacy and personality traits, that affects one's engagement in the CCS process and moderates the outcomes of the process. Figure 2 exhibits the theoretical and operationalized levels of the proposed model based on the discourse above. The model operationalizes individual dimensions of each stage in the Organizational Socialization Theory as the sub-constructs of the CCS process based on the SDL. The following section elaborates on the extant literature concerning the four major constructs and develops hypotheses to test their relationships.

\subsection{Hypotheses development}

\subsubsection{Tourist education and CCB}

A tourism company usually conducts tourist education to familiarize tourists who purchased tour packages with the tour information and requirements, such as tour brochures, travel itineraries, destination information, emergency procedures, behavioral codes, do's-and-don'ts, common practices, among others. Tourists as learners need to consider their unique learning styles. According to the concept of learning styles, the most effective instructional mode for each learner is different from one another (Pashler et al. 2008). For example, a tourist could be a visual learner, auditory learner, verbal learner, or kinesthetic learner (Willingham et al. 2015). Therefore, the tourism provider should offer customer-centric education to the tourists according to their individual learning styles. As such, this study defines tourist education as the educational provision of a tour company initiated by either the company or the tourists concerning the information needs of the tour group or specific individuals according to individuals' learning styles: namely, standardized education for the tour group and personalized education for the individuals.

Regarding CCB, once the tourists set sail into their group journey, they must follow the group's normative behaviors as the adage says, "When in Rome, do as the Romans do." Nevertheless, a unique circumstance may occur in the journey that requires an innovative measure. An example may be an unexpected request from a tourist for a change in the tour package's itinerary to make a detour to a famous attraction that is not on the original schedule. Moreover, today's cell phones and mobile communication technologies allow tourists to retrieve ample information 
about destination sites and make their own tour arrangements to travel alone effectively. This kind of innovative behavior is very common among today's tourists. This study argues that both normative co-production and innovative co-creation patterns are embedded in each of the three distinct aspects: proactive prevention, proactive learning, and proactive feedback (Challagalla et al. 2009).

In a post-sale service like a packaged tour, tourists are concerned about the proactivity of education/learning, prevention, and feedback-seeking exerted by the tour company (Challagalla et al. 2009). Therefore, these are critical to the VCC of travel agents during the tour-package delivery process. Meanwhile, they are central to the tourists' VCC as it requires both parties to behave proactively. Proactive prevention is the tourists' proactive cooperation with a travel agent to prevent specific individuals or groups from encountering potential problems during a tour. Proactive feedback refers to tourists' tendencies to initiate communication with the travel agent regarding their individual or group needs/problems and respond to the tour company's feedback solicitation. Finally, proactive learning refers to tourists' proactive ways of learning knowledge and information (e.g., culture and customs about the destination) provided by either the travel agent or self-initiated search to enrich the travel experience before or during the trip. Therefore, this study adopts these three dimensions as a surrogate of tourist CCB.

Tourist education aims to socialize the tourists to understand the processes, regulations, and benefits of the tour company's services and acquire skills for using the services. Liao et al. (2017) reported that customer socialization by such education is helpful for them, especially when they encounter problems in using services, and increases their intention to participate in VCC activities. This clear objective enables the tourists to trust the company, encouraging them to participate in VCC (See-To and Ho 2014). Moreover, the interest and enthusiasm of the company in excavating and fulfilling tourists' personal needs may touch the hearts of the tourists and induce them to collaborate with the company for co-creating the tour experiences, which could continuously shape the tourists' perceptions and understanding of the tour companies' expectations about their roles (Lengnick-Hall et al. 2000). Consequently, tourists might feel obligated and excited to engage in VCC. During tourist education, frequent interactions between tourists and the company may improve their relationships and increase tourists' identification with the company (Reichers 1987). As a result, they are prone to commit to and perform VCC activities. Taking these together, we propose the following hypothesis:

\section{H1 Tourist education positively affects tourist CCB.}

\subsubsection{Co-creation readiness and behavior}

A tourist's readiness is an essential prerequisite for effective co-creation with the travel agency. This readiness derives from tourists' understanding of their roles and why and how to perform the roles. Meuter et al. (2005) adapt three dimensionsrole clarity, ability, and motivation-from Vroom (1964) and Bowen (1986) and develop a measure of customer readiness to indicate a condition or state in which a consumer is prepared and likely to engage in a service. Role clarity refers to a 
customer's knowledge and understanding of what to do in service; ability refers to perceived skills and confidence to complete the task; motivation is a desire to receive the rewards for using the service (Meuter et al. 2005). Furthermore, they regard customer readiness as the prerequisite of customer co-production behavior. Bowen (1986) also explains how a company can improve customer co-production by harnessing these three critical dimensions from a human resource perspective.

Adapted from Meuter et al. (2005), Dong et al. (2015) defined customer participation readiness in the service process as "the extent to which a customer is prepared to participate in service production and delivery" (p. 3) and consists of three factors: role identification, perceived ability, and perceived benefit of participation. Specifically, role identification refers to "the degree to which customers accept and internalize their roles in service participation" (Dong et al. 2015, p. 4), somewhat different from the "role clarity" definition in Meuter et al. (2005). Perceived ability refers to a customer's perceived knowledge and skills to perform a task effectively, while the perceived benefit of participation refers to the customer's evaluation of the participation benefits (Dong et al. 2015); both are consistent with the terms of Meuter et al. (2005). Therefore, drawing on the studies of Meuter et al. (2005) and Dong et al. (2015), we define CCR as the extent to which a tourist is ready to perform role-oriented behaviors during the tour-service delivery process consisting of three constructs: role clarity, perceived ability, and motivation. Without all these constructs, CCR is not complete and CCB cannot occur (Meuter et al. 2005).

Following the CCS process proposed in this study for a tourism company, we reason that tourist CCR indicates a tourist's clear understanding of his/her custodial and innovative roles and knowing why and how to perform these roles and have a desire to receive the benefits from CCBs. In particular, the custodial role means that the tourists understand their duties in the tour group and follow them responsibly, e.g., flight time, check-in and check-out time, and responsive requests. Thus, they would make the tour safe and effective for the group. In contrast, the innovative role refers to tourists' free choice to perform personal activities according to their individual needs, such as personalized room requests, schedule changes, and private tour explorations. By doing so, they would create more value from the tour. That is, when tourist CCR exists, tourists could no longer remain as bystanders and would most likely transform themselves into proactive tourists and be ready to play custodial and innovative roles. Therefore, in the CCS process, we postulate that tourist CCR can trigger the roles-oriented CCB. Hence, we hypothesize,

\section{H2 Tourist CCR positively affects tourist CCB.}

\subsubsection{Tourist education and CCR}

To ensure service delivery, companies explicitly or implicitly define role expectations of what customers should do and what information they should provide (Solomon et al. 1985; Rollag 2012). A proper socialization program helps customers understand their roles and role expectations; it prevents dysfunctional behaviors and speeds up service flow and productivity (Rollag 2012). In this study, the means of a customer-centric socialization program is tourist education with standardized and 
personalized tactics, and the end is tourists' understanding of custodial and innovative roles. On the one hand, tourist education helps tourists comprehend their custodial roles, i.e., the tour group's role expectations. On the other hand, tourist education also helps tourists clarify their innovative roles, i.e., the role expectations of their personal needs. Tourist education shall provide information and advice responsively to tourists and explain why and how to perform the custodial and innovative roles, according to individual learning styles. Based on these materials, the tourists could establish skills and knowledge to perform both roles. They interact and collaborate with the travel agent proactively to make good use of the tour services. Besides, tourist education could make the tourists qualify for knowledge-intensive tour activities such as searching for additional travel information and absorbing the culture's implicit characteristics, among others.

In the context of service delivery, socialization activities transmit clear messages to new customers that they can receive the benefits of increasing control over product/service delivery, time savings, or even monetary savings when their role expectations are met or exceeded (Bowen 1986). In this study, tourist education enhances the benefits-aspect of tourist CCR after the tourists learn and understand what and how to perform their custodial and innovative roles during the journey. Knowing these three W's (what, how, and why), the tourists can increase readiness to perform their roles-oriented tasks. Based on the discourse above, tourist education can successfully shape tourists' role orientations and engender CCR. Thus, we propose,

H3 Tourist education positively affects tourist CCR.

\subsubsection{Co-creation readiness as a mediator in the CCS process}

Based on hypotheses $\mathrm{H} 1, \mathrm{H} 2$, and $\mathrm{H} 3$, tourist CCR partially mediates tourist education and CCB. This relationship is confirmed by prior studies (Bauer et al. 2007; Saks et al. 2007), wherein proximal adjustment outcomes (e.g., role clarity, selfefficacy, and perceived job/organization fit) partially mediate the relationships between socialization tactics (i.e., institutionalized and individualized tactics) and distal adjustment outcomes (e.g., job satisfaction, organizational commitment, and job performance). Specifically, in this study, tourist education establishes tourist CCR and subsequently triggers CCB. Furthermore, standardized and personalized tourist-education tactics involve frequent interactions that help establish a stable tourist-company relationship and increase tourists' identification with the company (Reichers 1987). These results motivate the tourist to commit to and perform VCC activities during the CCS process. In this vein, tourist education still directly affects $\mathrm{CCB}$ even though tourist CCR is a mediator between them. Thus, we postulate,

H4 Tourist CCR partially mediates the positive effect of tourist education on CCB. 


\subsubsection{Personal involvement in tourism as a moderator in the CCS process}

Individual differences, such as self-efficacy (Eden and Aviram 1993) and personality traits (Kammeyer-Mueller and Wanberg 2003), can influence socialization outcomes. Commonly, scholars have dichotomized self-efficacy into general selfefficacy (Eden 1988) versus specific self-efficacy (Eden and Aviram 1993; Bandura 1997). While general self-efficacy refers to the "trait-like self-perceptions of the ability to effect requisite performances as it generalizes across a wide variety of situations" (Eden 1988; Eden and Aviram 1993, p. 353), specific self-efficacy refers to particular forms of self-efficacy, e.g., academic, parenting, sports, software, computer, among others (Bandura 1997; Nielsen et al. 2017). Although individual differences in the general self-efficacy could impact customers' learning speed and information absorption, the specific self-efficacy can be trained well enough to perform a situation-specific task through the socialization process (Eden and Aviram 1993). Thus, as a trait-like self-perception of one's ability, general self-efficacy is not highly concerned during the socialization process.

Moreover, personality traits, coupled with interests, intrinsic motivation, and exploration, can affect socialization (Silvia 2006). Specifically, people who are extravert and open to experience often proactively seek information and feedback, positively frame new situations as opportunities rather than threats, and eagerly build relationships with others (Kammeyer-Mueller and Wanberg 2003). This characteristic is similar to personal involvement in an object when "a person's perceived relevance of the object based on inherent needs, values, and interests" (Zaichkowsky 1985, p. 342). Many tourism and leisure studies have used it as a moderator (Mathis et al. 2016). This study adopts the concept of personal involvement in tourism from Zaichkowsky (1994), which defines it as a psychological state of passion for travel. Specifically, tourists with personal involvement are passionate about travel and may react differently to role orientation and behavior in the CCS process.

Due to individual differences in personal involvement, role-orientation adjustment facilitated by standardized and personalized education shall differ. The tourists with a high level of involvement usually have a passion for travel, and the traveling experience is central to their lives. They actively learn and seek information about locals, services, sightseeing spots, and potential problems related to the destination (McIntyre 1989). This passion primes them with high expectations about experiential values and independence from the tour activities. Meanwhile, individuals with low-level involvement have no knowledge to produce memorable holiday experiences; consequently, they need the tourism provider's active support in providing the necessary knowledge and useful information to prepare for a pleasant journey. Therefore, tourist education's helpfulness in increasing tourist CCR and CCB would be contingent on the tourists' passion for travel. People with high involvement mainly look for high-quality and useful information (Park et al. 2007). Instructions and guidance from the travel company with which they are very familiar offer no added value and are considered a waste of time. Moreover, the psychology of "if they already know it, then they do not have to engage in learning it" (Roth 2019, p. 23) may stifle the moderation effect, making tourist education less important to 


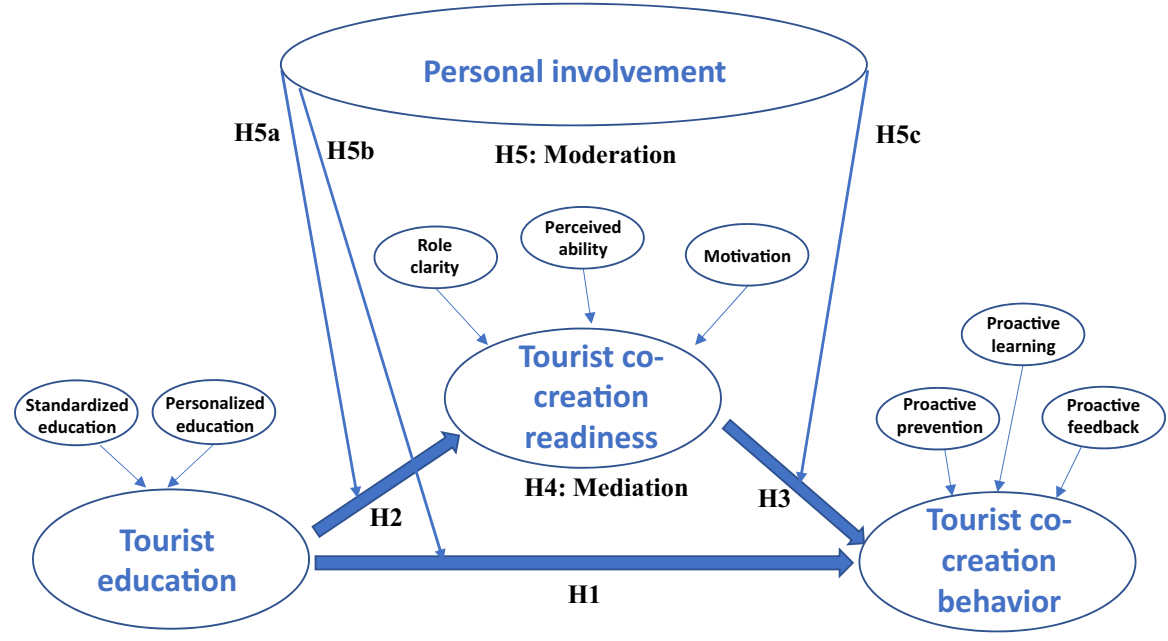

Fig. 3 Research model with hypotheses

tourist CCR and CCB when a tourist's involvement is high. In this vein, we hypothesize as follows:

H5a Personal involvement moderates the relationships of tourist education with tourist CCR.

H5b Personal involvement moderates the relationships of tourist education with tourist CCB.

Moreover, scholars have reported that consumers with higher involvement are more likely to participate in a company's new product development process (Füller et al. 2009). Therefore, we assume that tourists with high involvement are more likely to perform co-creation actively during the journey. They seek excitement by exploring the tour that offers new and creative experiences because they have abundant tourism knowledge (Diamantis 1999). In other words, they are expert travelers and have a strong intrinsic motivation to self-search for what and how to perform co-creation tasks. Thus, high-involvement tourists can selfdevelop more of their readiness after they receive encouragement from tourist education. That is, they co-create values even more proactively with the travel agency than low-involvement tourists do whenever possible. As such, their involvement significantly affects their CCB. Based on the above discourse, we hypothesize as follows:

H5c Personal involvement moderates the relationship between CCR and CCB.

Taking H5a, H5b, and H5c together, we postulate the following hypothesis of moderated mediation. 
H5 Personal involvement moderates the strength of the partially mediated relationship between tourist education and CCB via CCR.

Based on the above discourse, we develop a research model containing the five hypotheses in Fig. 3. The methodology for validating this model is as follows:

\section{Methodology}

\subsection{Measures}

Most constructs in this study were adopted from prior studies, except the constructs of CCB and personalized education. Table 2 exhibits all measurement scales and their factor loadings and t-values. Particularly for CCB, we developed measurement items according to the three dimensions described in Challagalla et al. (2009). We first reviewed several renowned travel agencies' service offerings in the preconsumption and consumption stages (e.g., traveling notes, package instructions, feedback-seeking, and others). Then, we classified these offerings according to travel agencies' VCC activities and modified the items to fit the operational definition of CCB. This process resulted in a 5-item scale for each construct. Using exploratory factor analysis, we removed those items with loadings smaller than 0.40 , leaving 3 or 4 items for each construct (see Table 2). Furthermore, we conceptualized CCB as a formative second-order construct with the three dimensions as the sub-constructs.

Co-creation readiness was also conceptualized as a formative second-order construct consists of three dimensions: role clarity, perceived ability, and motivation, each with a 3-item scale adapted Meuter et al. (2005) and Dong et al. (2015). Similarly, tourist education was conceptualized as a formative second-order construct. We adapted three items from Eisingerich and Bell (2008) to measure standardized education and self-developed five items to measure personalized education. These five items were identified from personalized service situations in the tourism literature. Using exploratory factor analysis, we removed those items with loadings smaller than 0.40, leaving three items for the personalized-education construct.

Ten items adapted from Zaichkowsky (1994) measured personal involvement with a differential semantic scale ranging from 1 to 6 (e.g., $1=$ not exciting; $6=$ very excited). All items of the other constructs used a 6-point scale, ranging from " 1 " (strongly disagree) to " 6 " (strongly agree). We followed Si and Cullen (1998) to use even-number scales because Asian respondents tend to value modesty and select the midpoint of a scale more often than western counterparts.

\subsection{Data collection}

After designing the questionnaire based on the scales reported in the literature, we first organized a focus-group meeting to check whether the survey's wording was clear to all respondents and ensure the measurement items' face validity. The 
Table 2 Measurement items

Second-order construct

Factor loading

First-order construct

\section{Tourist education}

\section{Standardized education (SE)}

SE1: The travel agency clearly explains the pros and cons of the different tour packages (or itineraries) they recommended to me

SE2: The travel agency explains the recommended tour packages (or itineraries) according to my learning styles

SE3: The travel agency explains what is going on with my travel itinerary or tour activities

\section{Personalized education (PE)}

PE1: The travel agency offers me competently all the information and advice I requested according to my learning styles

PE2: The travel agency is responsive to my requests for personal plan-related information and advice

PE3: The travel agency cares very much about my personal needs for tour-related education

Tourist co-creation readiness $(C C R)$

\section{Role clarity $(\mathbf{R C})$}

$\mathrm{RC} 1$ : I am fully aware of my role as a tourist during the tour. (IR $+\mathrm{CR}, \mathrm{CP}+\mathrm{CC}$ )\#

$\mathrm{RC} 2$ : I know what is expected of me as a tourist to make the travel experience better. $(\mathrm{IR}+\mathrm{CR}, \mathrm{CP}+\mathrm{CC}) \#$

RC3: I know very well about my duties as a tourist during the tour. (IR $+\mathrm{CR}$, $\mathrm{CP}+\mathrm{CC}) \#$

\section{Perceived ability (PA)}

PA1: I am confident in proactively interacting with the travel agent to ask for the roles-related tour information (e.g., visiting places or requesting services). (IR + $\mathrm{CR}, \mathrm{CP}+\mathrm{CC}) \#$

PA2: I am qualified for engaging in the roles-related knowledge-intensive tour activities (e.g., searching for additional travel information and absorbing implicit characteristics of a culture). (IR $+\mathrm{CR}, \mathrm{CP}+\mathrm{CC}) \#$

PA3: I can fully collaborate with the travel agent to make the roles-related tour plan (e.g., planning schedules and personalizing routes). (IR $+\mathrm{CR}, \mathrm{CP}+\mathrm{CC}) \#$

\section{Motivation (MO)}

MO1: I am motivated to perform tour activities to get what I want from the tour. $(\mathrm{IR}+\mathrm{CR}, \mathrm{CP}+\mathrm{CC}) \#$

MO2: I am motivated to perform tour activities to have a safe and joyful trip. (IR+ $\mathrm{CR}, \mathrm{CP}+\mathrm{CC}) \#$

MO3: I am motivated to perform tour activities to improve my travel experiences. $(\mathrm{IR}+\mathrm{CR}, \mathrm{CP}+\mathrm{CC}) \#$

Tourist co-creation behavior $(C C B)$

\section{Proactive prevention (PP)}

PP1: I always prepare appropriate clothing for destination weather based on the travel agent's advice. (NB, CP)\#

PP2: I always comply with the travel agent's precautions to prepare my supplies (e.g., medicine, swimsuit) for the journey. (IB, CC)\#

PP3: I always pay attention to the travel agency's policies to prevent disappointing travel experiences. $(\mathrm{NB}, \mathrm{CP}) \#$ 
Table 2 (continued)

Second-order construct

Factor loading

First-order construct

PP4:I always follow the planned schedule closely to avoid causing trouble to the

0.857 tour. (NB, CP)\#

\section{Proactive learning $(\mathrm{PL})$}

PL1: I always take time to go through the planned schedule of travel activities. (NB, CP)\#

PL2: I always read in advance the safety-related information provided by the travel agency. (NB, CP)\#

PL3: I always read the travel agency's information (e.g., the destination's customs) carefully. (NB, CP)\#

PL4: While joining a tour, I always spend the effort to learn about the destination attractions. (IB, CC)\#

\section{Proactive feedback (PF)}

PF1: I take as much time as possible to share my preferences to help the travel agent design my travel plan. (IB, CC)\#

PF2: I take the initiative to inform the travel agent of my special requests (e.g., special diet, extra bed) before departure. (IB, CC)\#

PF3: I provide feedback whenever possible to help the travel agency improve its service quality. (NB, IB, CC)\#

Personal involvement $(P I)$

In my opinion, to travel is...

PI1: Not important $\leftrightarrow$ Very important

PI2: Not interesting $\leftrightarrow$ Very interesting

PI3: Not related $\leftrightarrow$ Closely related

PI4: Not exciting $\leftrightarrow$ Very exciting

PI5: Not meaningful $\leftrightarrow$ Very meaningful

0.828

PI6: Not attractive $\leftrightarrow$ Very attractive

0.908

PI7: Tedious $\leftrightarrow$ Enchanting

PI8: Not valuable $\leftrightarrow$ Very valuable

PI9: Not want to join $\leftrightarrow$ Want to join

PI10: Dispensable $\leftrightarrow$ Very necessary

0.816

Note: $I R$ innovative role, $C R$ custodial role; $N B$ normative behavior, $I B$ innovative behavior, $C P$ co-production, $C C$ co-creation

\#Parenthesized acronym indicates the role/behavior/mode supported by the scale item

meeting consists of the authors (i.e., 2 graduate students and 2 senior professors) and 6 managers from different travel companies. They are all bilingual in English and Chinese. As the survey was administered in Chinese, we needed to perform translation and back translation to ensure the semantic consistency of each questionnaire item between English and Chinese (Brislin 1970). First, the graduate students translated the original question items in English to Chinese, and one senior professor edited the translation. Then, two industry managers who had never seen the questionnaire translated these Chinese items back to English. Next, the remaining four industry managers and one senior professor formed a panel to 
assess each back-translated item to make sure the meaning of the original item was well preserved. The measurement items were then revised according to the suggestions from the panel. Finally, we conducted a pilot test using the revised questionnaire and collected a convenient purposive sample of 30 tourists from a leading Facebook traveling fan page in Taiwan (see https:/www.facebook.com/ Traveling.tw/) who had experiences in packaged tours. Based on the results of the pilot test, we further adjusted and refined the measurement items. The result shows acceptable reliability and validity of what we want to measure.

To collect survey data, we posted an announcement on the same leading Facebook traveling fan page in Taiwan soliciting over 582,000 members to participate in a survey. The announcement contained a hyperlink that allowed each participant to click the hyperlink and go directly to the online questionnaire website. We also offered an incentive on the announcement to increase the response rate, indicating that $10 \%$ of the respondents would be randomly selected to receive US\$7 vouchers. The announcement was posted twice and two weeks apart. To qualify for the survey, the participants must have purchased overseas tour packages and attended pre-tour educational workshops in Taiwan. Four weeks later, from January 1 to January 31, 2020, we received 250 qualified respondents. After eliminating 10 responses with duplicate IP addresses and 13 responses with many missing values, we obtained 227 valid questionnaires. Table 3 presents the demographic characteristics of usable respondents.

\section{Results}

\subsection{Measurement validation}

This study used structural equation modeling (SEM) with partial least squares (PLS) to analyze the latent variables and test the hypotheses. Compared with covariancebased SEM, PLS-SEM can handle better non-normally distributed data. As the data of the latent variables in this study are non-normally distributed (kurtosis $>3$ ), PLS-SEM is considered more suitable for analysis. We examined construct reliability, convergent validity, and discriminant validity for reflective first-order constructs. All factor loadings in Table 3 were greater than the cutoff of 0.7 and significant at the $p<0.001$ level, while Table 4 shows that the average variance extracted of each construct was larger than the cutoff value of 0.5 (Fornell and Larcker 1981), indicating good convergent validity. Furthermore, all the constructs had composite reliability over the cutoff of 0.70 recommended by Fornell and Larcker (1981). The average variance extracted (AVE) measures the variance between a construct and its indicator. The discriminant validity exists when the square root of the AVE from a construct is larger than all correlations between the construct and the other constructs in the model (Fornell and Larcker 1981). Table 5 shows that all model constructs' data satisfied this criterion, confirming the discriminant validity.

The process of examining the validity of a formative second-order construct is to examine the weights of indicators. Table 6 shows that the weights of the indicators were all significant at $p<0.001$, suggesting that the three formative second-order 
constructs have good quality and confirming the validity of all second-order constructs (Petter et al. 2007). To assess the common method variance (CMV), we conducted Harman's single-factor test (Podsakoff et al. 2003) and found the single factor only explained $39.53 \%$ of the variance, indicating that CMV was not significant in this study.

\subsection{Hypotheses testing}

We used SmartPLS 3.0 to test the direct effects of $\mathrm{H} 1, \mathrm{H} 2$, and $\mathrm{H} 3$. The results showed that all effects were significantly positive at $p<0.001$. To test $\mathrm{H} 4$, we analyzed the mediation model with three constructs following the criteria of a mediation effect suggested by Preacher and Hayes (2004). First, the direct effects were all significant at $p<0.05$. Next, the indirect-effect test indicated that tourist education had a significantly positive effect on CCB via the mediation of CCR $(\beta=0.359)$ with the bootstrap $95 \%$ confidence interval higher than zero. Lastly, the mediation effect of CCR was significant. The direct effect of tourist education on CCB was 0.160 and significant at $p<0.05$, indicating a partial mediation (Preacher and Hayes 2004) and supporting H4. Table 7 exhibits the results of testing $\mathrm{H} 1$ to $\mathrm{H} 4$.

To support the moderated mediation effects postulated in $\mathrm{H} 5$, the interaction effects of personal involvement on the three paths of mediating effects should be significant. To test these effects, we used model 59 of the PROCESS macro from Hayes (2013). First, CCR entered as a mediator between tourist education and CCB and personal involvement as a moderator. Table 7 shows that the direct effects of tourist education on CCR $(\beta=0.4468 ; p<0.001)$ and CCB $(\beta=0.1716 ; p<0.01)$, and CCR on CCB $(\beta$ $=0.4035 ; p<0.001)$ were significant. The direct effects of personal involvement on $\operatorname{CCR}(\beta=0.3052 ; p<0.001)$ and $\operatorname{CCB}(\beta=0.1257 ; p<0.05)$ were significant as well. Next, the interaction effect of personal involvement $\times$ tourist education on CCR was

Table 3 Demographic characteristics of the respondents $(\mathrm{N}=227)$

\begin{tabular}{llr}
\hline Category & Frequency & Percentage \\
\hline Gender & & \\
Male & 99 & 43.6 \\
Female & 128 & 56.4 \\
Age & & \\
18 and under & 1 & 0.1 \\
19 to 24 & 78 & 34.4 \\
25 to 34 & 73 & 32.2 \\
35 to 44 & 12 & 5.3 \\
45 to 54 & 29 & 12.8 \\
55 and above & 34 & 15.0 \\
Education & & \\
High school & 13 & 5.7 \\
College & 158 & 69.6 \\
Graduate & 53 & 23.3 \\
Doctoral degree & 3 & 1.3 \\
\hline
\end{tabular}


significant $(\beta=-0.181 ; p<0.001)$, supporting H5a. However, the interaction effects of personal involvement $\times$ tourist education and personal involvement $\times$ co-creation readiness on CCB were not significant; thus, H5b and H5c were not supported. Finally, in the test of the conditional indirect effect using model 59, CCR significantly mediated tourist education's influence on CCB in both high and low levels of personal involvement. Particularly, tourist education on $\mathrm{CCB}$ via $\mathrm{CCR}$ was significant and stronger in low-level personal involvement $(\beta=0.288 ; 95 \%$ confidence interval $=[0.0938,0.4727])$ but weaker in high-level personal involvement $(\beta=0.100 ; 95 \%$ confidence inter$\mathrm{val}=[0.0271,0.2470])$.

\subsection{Analysis of interaction effect}

Since the moderation effect H5a of personal involvement was significant, its interaction-effect diagram should be examined. Figure 4 shows that when the tourist education level was high, the mean CCR levels of both personal-involvement groups (5.2140 and 5.3596) remained higher than the grand mean level of CCR in the entire sample (4.9828). However, when the tourist education level was low, the high-level personal-involvement group had a mean CCR level (4.4283) lower than the grand mean CCR level, but the low-level personal-involvement group had a mean CCR level (5.0260) higher than the grand mean. This finding implies that the tourists involved intensively with tours considered poor-quality tourist education useless and counterproductive, while the weakly involved tourists thought that poor-quality education could still help them prepare some readiness for co-creation.

Table 4 Summary statistics of constructs

\begin{tabular}{llllll}
\hline Construct & No. of items & Mean (std. dev.) & $\begin{array}{l}\text { Composite } \\
\text { reliability }\end{array}$ & $\begin{array}{l}\text { Average vari- } \\
\text { ance extracted }\end{array}$ & $\begin{array}{l}\text { Variance inflation } \\
\text { factor }\end{array}$ \\
\hline $\begin{array}{l}\text { Standardized educa- } \\
\text { tion }\end{array}$ & 3 & $4.73(0.81)$ & 0.91 & 0.78 & 4.61 \\
$\begin{array}{l}\text { Personalized educa- } \\
\text { tion }\end{array}$ & 3 & $4.67(0.87)$ & 0.94 & 0.84 & 4.86 \\
Role clarity & 3 & $4.98(0.67)$ & 0.91 & 0.77 & 4.10 \\
Perceived ability & 3 & $4.93(0.67)$ & 0.88 & 0.72 & 3.95 \\
Perceived benefits & 3 & $5.03(0.64)$ & 0.88 & 0.71 & 4.49 \\
$\begin{array}{l}\text { Proactive prevention } \\
\text { Proactive learning }\end{array}$ & 4 & $5.33(0.62)$ & 0.91 & 0.72 & 2.67 \\
$\begin{array}{l}\text { Proactive feedback } \\
\text { Personal involve- }\end{array}$ & 3 & $5.05(0.67)$ & 0.87 & 0.63 & 2.41 \\
$\quad 10$ & $4.88(0.72)$ & 0.90 & 0.74 & 1.92 \\
$\quad$ ment & $5.32(0.74)$ & 0.96 & 0.69 & Not applicable \\
\hline
\end{tabular}


Table 5 Correlation matrix and discriminant validity

\begin{tabular}{llllllllll}
\hline Construct & 1 & 2 & 3 & 4 & 5 & 6 & 7 & 8 & 9 \\
\hline 1. Standardized education & $\mathbf{0 . 8 8 1}$ & & & & & & & & \\
2. Personalized education & 0.879 & $\mathbf{0 . 9 1 9}$ & & & & & & & \\
3. Role clarity & 0.485 & 0.532 & $\mathbf{0 . 8 7 8}$ & & & & & & \\
4. Perceived ability & 0.522 & 0.557 & 0.794 & $\mathbf{0 . 8 4 6}$ & & & & & \\
5. Motivation & 0.470 & 0.485 & 0.816 & 0.828 & $\mathbf{0 . 8 4 1}$ & & & & \\
6. Proactive prevention & 0.413 & 0.398 & 0.661 & 0.596 & 0.675 & $\mathbf{0 . 8 5 0}$ & & & \\
7. Proactive learning & 0.460 & 0.443 & 0.615 & 0.544 & 0.574 & 0.705 & $\mathbf{0 . 7 9 5}$ & & \\
8. Proactive feedback & 0.472 & 0.471 & 0.511 & 0.548 & 0.566 & 0.578 & 0.585 & $\mathbf{0 . 8 6 3}$ & \\
9. Personal involvement & 0.195 & 0.228 & 0.489 & 0.432 & 0.436 & 0.414 & 0.395 & 0.347 & $\mathbf{0 . 8 3 0}$ \\
\hline
\end{tabular}

Each diagonal element is the square root of average variance extracted; off-diagonal numbers represent the correlations among constructs

Table 6 Validity of formative second-order construct

\begin{tabular}{lll}
\hline Second-order construct & First-order construct & Weight \\
\hline Tourist education (formative) & Standardized education & $0.485^{* * *}$ \\
& Personalized education & $0.546^{* * *}$ \\
Co-creation readiness (formative) & Role clarity & $0.380^{* * *}$ \\
& Perceived ability & $0.336^{* * *}$ \\
& Perceived benefits & $0.353^{* * *}$ \\
Co-creation behavior (formative) & Proactive prevention & $0.452^{* * *}$ \\
& Proactive learning & $0.389^{* * *}$ \\
& Proactive feedback & $0.306^{* * *}$ \\
\hline
\end{tabular}

$* * * \mathrm{p}<0.001$

\section{Discussion and conclusion}

\subsection{Conclusion}

In this paper, we collected tourist data from the leading Facebook traveling fan page in Taiwan and found that tourist education implemented by standardized and personalized education is a powerful and relevant CCS strategy influencing CCB. This finding confirms the notion that high-quality tourist education can build up tourists' capability of learning and understanding the tourism company's value proposition, leading to active engagement in CCB (Payne et al. 2008). It also answers the call for a research agenda on imparting tourists with suitable know-how to engage in cocreation effectively (Santos-Vijande et al. 2015).

This study further confirms that CCR mediates the relationship between tourist education and CCB. Moreover, it shows that low personal involvement influences the relationships between tourist education and CCR more than high involvement does. The study also reveals that high-quality tourist education can create high CCR, 
Table 7 Hypotheses testing results

\begin{tabular}{lllrll}
\hline Hypothesis & Relationship & $\begin{array}{l}\text { Standardized } \\
\text { coefficient }\end{array}$ & $t$-value & $p$-value & Result \\
\hline $\mathrm{H} 1$ & $\mathrm{TE} \rightarrow \mathrm{CCB}$ & 0.519 & 6.576 & $<0.001$ & Supported \\
$\mathrm{H} 2$ & $\mathrm{CCR} \rightarrow \mathrm{CCB}$ & 0.730 & 10.845 & $<0.001$ & Supported \\
$\mathrm{H} 3$ & $\mathrm{TE} \rightarrow \mathrm{CCR}$ & 5.561 & $<0.001$ & Supported \\
$\mathrm{H} 4:$ Partial mediation & effect of co-creation readiness $(C C R)$ & & & \\
Direct effect & $\mathrm{TE} \rightarrow \mathrm{CCB}$ & 0.160 & 2.386 & $<0.001$ & Supported \\
Direct effect & $\mathrm{CCR} \rightarrow \mathrm{CCB}$ & 0.640 & 9.273 & $<0.001$ & Supported \\
Direct effect & $\mathrm{TE} \rightarrow \mathrm{CCR}$ & 0.561 & 5.680 & $<0.001$ & Supported \\
Indirect effect & $\mathrm{TE} \rightarrow \mathrm{CCR} \rightarrow \mathrm{CCB}$ & 0.359 & 4.153 & $<0.001$ & Supported \\
& & $0.561 \times 0.640=0.359$ is within $95 \%$ bootstrap confidence
\end{tabular}

H5: Moderated mediation effects of personal involvement (PI)

Results from Model 59:

\begin{tabular}{llllll} 
Direct effect & $\mathrm{TE} \rightarrow \mathrm{CCR}$ & 0.4468 & 9.5354 & $<0.001$ & Supported \\
Direct effect & $\mathrm{PI} \rightarrow \mathrm{CCR}$ & 0.3052 & 6.3446 & $<0.001$ & Supported \\
Direct effect & $\mathrm{TE} \rightarrow \mathrm{CCB}$ & 0.1716 & 2.9947 & $<0.01$ & Supported \\
Direct effect & $\mathrm{CCR} \rightarrow \mathrm{CCB}$ & 0.4035 & 5.9426 & $<0.001$ & Supported \\
Direct effect & $\mathrm{PI} \rightarrow \mathrm{CCB}$ & 0.1257 & 2.4704 & $<0.05$ & Supported \\
Interaction effect & $\mathrm{PI} \times \mathrm{TE} \rightarrow \mathrm{CCR}$ & -0.1813 & -6.4347 & $<0.001$ & Supported \\
Interaction effect & $\mathrm{PI} \times \mathrm{TE} \rightarrow \mathrm{CCB}$ & -0.0550 & -1.1351 & 0.2576 & Not supported \\
Interaction effect & $\mathrm{PI} \times \mathrm{CCR} \rightarrow \mathrm{CCB}$ & -0.0597 & -0.9839 & 0.3262 & Not supported \\
\hline
\end{tabular}

$T E$ tourist education, $P I$ personal involvement, $C C R$ co-creation readiness; $C C B$ co-creation behavior.

regardless of whether personal involvement is high or low. Therefore, tourism companies must avoid delivering poor-quality tourist education because it could weaken the CCR and, in turn, display less CCB. More seriously, poor-quality tourist education may turn away the high-involvement tourists, making them reluctant to perform CCB during the tour. In this vein, the quality of tourist education is of utmost importance to the CCS process's success.

\subsection{Theoretical contributions}

This study extends Jones' (1986) perspective of OST and the customer socialization concept of Kelley et al. (1990) into a process of three cyclical stages following the SDL principles. Previous studies (Mathis et al. 2016; Campos et al. 2017) on VCC in tourism emphasized VCC outcomes rather than the means of tourist education delivered by the tourism company to engender tourists' readiness for actual behavior. Additionally, Im and Qu (2017) advocate using experience environment (i.e., 
perceived physical environment and perceived support for customers) to generate VCC, which may depend on tourists' subjective decision on whether they want to engage in co-creation behavior or not. Alternatively, this study uses the lens of OST to evoke tourist co-creation behavior through tourist education proactively. It proposes the concept of tourist education with two modes of education (standardized versus personalized), which the tourism company could use as educational strategies. A deeper understanding of tourist education helps the firms more effectively enhance the tourist's proactive VCC. Thus, the result contributes to the extant tourism literature with a broader scope of tourist education. Furthermore, conceptualization with multiple dimensions of VCC in this study enhances a comprehensive understanding of co-creation aspects in service processes overlooked in prior studies (e.g., Grissemann and Stokburger-Sauer 2012; Campos et al. 2017).

Next, the identification of the CCS process contributes to the diverse approaches in the socialization literature. Previous studies often attribute service failure to the inadequate transfer of specialized skills and knowledge to customers in the service provision process (Dong et al. 2008). This study proposes that both tourists and tour providers should proactively pull and push information resources from each other to enhance the tourist's competence in co-creation activities (see Table 1), genuinely reflecting the philosophy of SDL in service provision. The result of this study implies that tourist education could make tourists become resource integrators (Vargo et al. 2008) who access, adapt, and integrate the firm's resources with their skills and knowledge through interactions with the firm during the tour. This discourse is consistent with previous studies (Santos-Vijande et al. 2015; GonzálezMansilla et al. 2019) in which the more accessible and transparent the firm's resources, the better the tourist in displaying CCB.

Finally, the previous empirical studies reveal that customers with high personal involvement are more knowledgeable about a product or a service they may

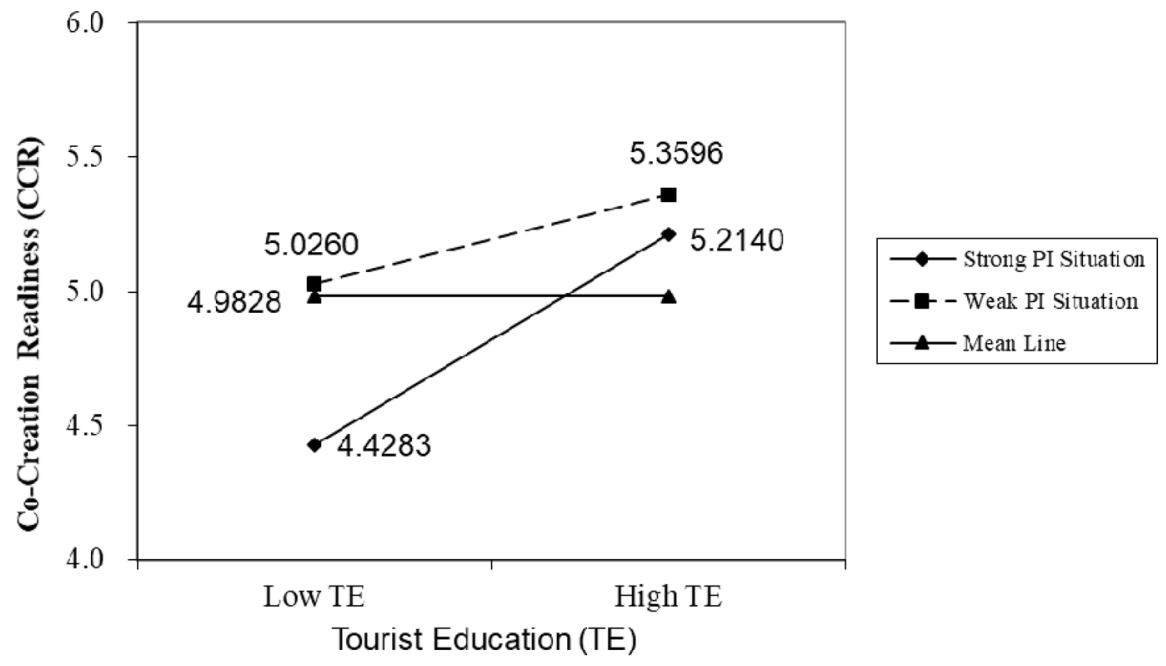

Fig. 4 Interaction effect diagram for personal involvement $(\mathrm{PI}) \times \mathrm{TE}$ on CCR 
purchase, causing them to evaluate the product/service carefully (Orazi et al. 2016). This situation happens in the tourism environment, especially after the highly involved tourists receive tourist education, making them more knowledgeable about the tour package to analyze the package's value. Surprisingly, our study reveals that the higher a tourist's involvement (i.e., more knowledgeable about the tour), the weaker the tourist education's influences on CCR. This result suggests that a company should understand individual differences when applying the CCS process to tourism. This insight contributes to the tourism literature on the role of individual differences in the socialization process.

\subsection{Managerial implications}

The findings of this study urge the tourism service to put the CCS process into practice. First, tourism companies could develop various information exchange channels to facilitate proactive co-creation activities between tourists and the company. During the COVID-19 pandemic, tourism companies could use various service interaction platforms such as mobile apps, e-commerce websites, virtual-reality-based touch-points to educate tourists with essential information related to destinations and their safety and well-being during the tour. Furthermore, they should be alert and prioritize health/safety-related issues (Li et al. 2021; Neuburger and Egger 2021). Clear guidance to tourists about how to travel safely (e.g., guidance in the car, on a plane, in a hotel, or at specific destinations) should be highlighted on the interaction platforms. By doing so, the tourist-company relationship could be enhanced and both sides could understand each other, making the tourists more ready and eager to interact with the company. With more knowledge about what and how to perform co-creation tasks, the tourists could generate more value. Therefore, the CCS process is more critical than ever in the pandemic.

Second, tourists with various levels of personal involvement respond differently to the company's socialization process. This finding implies that tourism companies should identify each tourist's involvement level to devise and adjust the CCS program that matches his/her knowledge and skills. During the pandemic, tourism marketers should compose travel guidelines for tourists according to their individual profiles, such as fully vaccinated or unvaccinated, chronic diseases, and personal requests for special services and diets necessary for engaging individual tourists in VCC. As a result, the CCS program brings competitive advantages to the companies and makes their competitors harder to imitate them.

\section{Limitations and future research}

There are a few limitations to this study. First, this study's findings could not be generalized because we collected the data from one leading Facebook traveling fan page in Taiwan and recruited anonymous volunteers via convenient purposive sampling. More tourism fan-page groups and more extensive sampling should be collected domestically and globally to overcome this weakness. 
Second, this study was conducted right before the COVID-19 pandemic outbroke in Taiwan in mid-February 2020. Therefore, the results of this study would be different during the pandemic, though the CCS process remains unchanged. For example, all tourists are concerned about health-related risks when traveling during the pandemic (Rather 2021); thus, they may proactively co-create with the tourism companies during the tour to minimize their risks. In this case, the level of personal involvement may not matter to the CCS process, leading to insignificant moderation effects. Furthermore, Taiwan's tourism industry suffered the most from COVID-19, forcing many travel companies to cease business in the first half of 2020 and leading to worries over layoffs and unpaid leave for employees (Aspinwall 2020). Such anxiety of employees could negatively influence the tourism employees' CCS performance. That is, the effects of tourist education on CCR and then CCB may be weakened. Therefore, additional research should be implemented during the pandemic to compare the differences in the CCS process with the current study.

Third, tourists' behavior is probably affected by psychological and economic factors in the pandemic period. Psychological factors include the fear of contracting the virus and the caution of travel (Yin and Ni 2021); the economic factor is the decrease in income (Kristal and Yaish 2020). In addition, social distance, isolation, and lockdown during the pandemic have changed consumer preference for using more digital platforms (Torkington 2021). Thus, the tourists' travel behavior is expected to change in the post-pandemic new normal. In particular, tourists would avoid public activities with a large crowd and prefer interaction on digital platforms. Thus, future research could investigate how such digital platforms facilitate the SSC process and affect tourists' VCC readiness and behaviors.

Finally, this study focuses on the co-creation between tourists and the company. Future research should include other stakeholders such as tour guides, local authorities, residents, and frontline service employees in the process. In addition, the effects on customer-centric socialization may come from the boundary conditions of tourism type (adventure vs. exploration), personality traits (risk-taking vs. risk-avoiding), situational involvement (honeymoon vacations vs. study trips), besides personal involvement. These potential boundary conditions are worth exploring in the future.

Acknowledgements This research was partially supported by the Ministry of Science and Technology in Taiwan (Grant Nos. 105-2410-H-007-033-MY3 and 108-2410-H-194-106-MY3). The authors give special thanks to Dr. Chenya Wang of the Institute of Service Science at National Tsing Hua University in Taiwan for her kind assistance in providing detailed reviews and constructive comments.

\section{Declarations}

Conflict of interests The authors declare that they have no conflict of interests. 


\section{References}

Aspinwall (2020) Taiwan braces for economic impact of global coronavirus outbreak. https://thedi plomat.com/2020/03/taiwan-braces-for-economic-impact-of-global-coronavirus-outbreak/. Accessed 18 Aug 2021

Bandura A (1997) Self-efficacy: the exercise of control. Macmillan, New York

Bauer TN, Bodner T, Erdogan B, Truxillo DM, Tucker JS (2007) Newcomer adjustment during organizational socialization: a meta-analytic review of antecedents, outcomes, and methods. J Appl Psychol 92(3):707-721. https://doi.org/10.1037/0021-9010.92.3.707

Bertella G (2014) The co-creation of animal-based tourism experience. Tour Recreat Res 39(1):115125. https://doi.org/10.1080/02508281.2014.11081330

Bowen DE (1986) Managing customers as human resources in service organizations. Hum Resour Manage 25(3):371-383. https://doi.org/10.1002/hrm.3930250304

Brislin RW (1970) Back-translation for cross-cultural research. J Cross Cult Psychol 1(3):185-216. https://doi.org/10.1177/135910457000100301

Büttgen M, Schumann JH, Ates Z (2012) Service locus of control and customer coproduction: the role of prior service experience and organizational socialization. J Serv Res 15(2):166-181. https:// doi.org/10.1177/1094670511435564

Cabiddu F, Lui TW, Piccoli G (2013) Managing value co-creation in the tourism industry. Ann Tour Res 42:86-107. https://doi.org/10.1016/j.annals.2013.01.001

Campos AC, Mendes J, do Valle PO, Scott N (2016) Co-creation experiences: attention and memorability. J Travel Tour Mark 33(9):1309-1336. https://doi.org/10.1080/10548408.2015.1118424

Campos AC, Mendes J, do Valle PO, Scott N (2017) Co-creating animal-based tourist experiences: attention, involvement and memorability. Tour Manag 63:100-114. https://doi.org/10.1016/j. tourman.2017.06.001

Campos AC, Mendes J, Valle PO, Scott N (2015) Co-creation of tourist experiences: a literature review. Curr Issues Tour 21(4):369-400. https://doi.org/10.1080/13683500.2015.1081158

Challagalla G, Venkatesh R, Kohli AK (2009) Proactive postsales service: when and why does it pay off? J Mark 73(2):70-87. https://doi.org/10.1509/jmkg.73.2.70

Chathoth P, Altinay L, Harrington RJ, Okumus F, Chan ES (2013) Coproduction versus co-creation: a process based continuum in the hotel service context. Int J Hosp Manag 32:11-20. https://doi. org/10.1016/j.ijhm.2012.03.009

Claycomb C, Lengnick-Hall CA, Inks LW (2001) The customer as a productive resource: a pilot study and strategic implications. J Bus Strategy 18(1):47-47

Crossley E (2020) Ecological grief generates desire for environmental healing in tourism after COVID-19. Tour Geogr 22(3):536-546

Diamantis D (1999) The characteristics of UK's ecotourists. Tour Recreat 24(2):99-102. https://doi. org/10.1080/02508281.1999.11014884

Dong B, Evans KR, Zou S (2008) The effects of customer participation in co-created service recovery. J Acad Mark Sci 36(1):123-137. https://doi.org/10.1007/s11747-007-0059-8

Dong B, Sivakumar K, Evans KR, Zou S (2015) Effect of customer participation on service outcomes: the moderating role of participation readiness. J Serv Res 18(2):160-176. https://doi.org/10. $1177 / 1094670514551727$

Eden D (1988) Pygmalion, goal setting, and expectancy: compatible ways to boost productivity. Acad Manage Rev 13(4):639-652. https://doi.org/10.5465/amr.1988.4307530

Eden D, Aviram A (1993) Self-efficacy training to speed reemployment: helping people to help themselves. J Appl Psychol 78(3):352-360. https://doi.org/10.1037/0021-9010.78.3.52

Eisingerich AB, Bell SJ (2008) Perceived service quality and customer trust: does enhancing customers' service knowledge matter. J Serv Res 10(3):256-268. https://doi.org/10.1177/1094670507 310769

Fornell C, Larcker DF (1981) Evaluating structural equation models with unobservable variables and measurement error. J Mark Res 18(1):39-50. https://doi.org/10.1177/002224378101800104

Füller J, Mühlbacher H, Matzler K, Jawecki G (2009) Consumer empowerment through internet-based co-creation. J Manag Inf Syst 26(3):71-102. https://doi.org/10.2753/MIS0742-1222260303

González-Mansilla Ó, Berenguer-Contrí G, Serra-Cantallops A (2019) The impact of value co-creation on hotel brand equity and customer satisfaction. Tour Manag 75:51-65. https://doi.org/10.1016/j. tourman.2019.04.024 
Grissemann US, Stokburger-Sauer NE (2012) Customer co-creation of travel services: the role of company support and customer satisfaction with the co-creation performance. Tour Manag 33(6):1483-1492

Guo L, Arnould EJ, Gruen TW, Tang C (2013) Socializing to co-produce: pathways to consumers' financial well-being. J Serv Res 16(4):549-563. https://doi.org/10.1177/1094670513483904

Hamilton K, Alexander M (2013) Organic community tourism: a cocreated approach. Ann Tour Res 42:169-190. https://doi.org/10.1016/j.annals.2013.01.015

Hayes AF (2013) Introduction to mediation, moderation, and conditional process analysis: a regressionbased approach. Guilford Publications, New York

Hoang TG, Truong NT, Nguyen TM (2021) The survival of hotels during the COVID-19 pandemic: a critical case study in Vietnam. Serv Bus 15(2):209-229. https://doi.org/10.1007/s11628-021-00441-0

Hong SG, Lee HM (2015) Developing Gamcheon Cultural Village as a tourist destination through cocreation. Serv Bus 9(4):749-769. https://doi.org/10.1007/s11628-014-0252z

IATA (2020) Recovery delayed as international travel remains locked down. https://www.iata.org/en/ pressroom/pr/2020-07-28-02/. Accessed 29 Aug 2021

Ihamäki P (2012) Geocachers: the creative tourism experience. J Hosp Tour Technol 3(3):152-175. https://doi.org/10.1108/17579881211264468

Im J, Qu H (2017) Drivers and resources of customer co-creation: a scenario-based case in the restaurant industry. Int J Hosp Manag 64:31-40. https://doi.org/10.1016/j.ijhm.2017.03.007

Jaakkola E, Helkkula A, Aarikka-Stenroos L (2015) Service experience co-creation: conceptualization, implications, and future research directions. J Serv Manag 26(2):182-205. https://doi.org/10.1108/ JOSM-12-2014-0323

Jones GR (1986) Socialization tactics, self-efficacy, and newcomers' adjustments to organizations. Acad Manage J 29(2):262-279. https://doi.org/10.5465/256188

Kammeyer-Mueller JD, Wanberg CR (2003) Unwrapping the organizational entry process: disentangling Disentangling multiple antecedents and their pathways to adjustment. J Appl Psychol 88(5):779794. https://doi.org/10.1037/0021-9010.88.5.779

Kelley SW, Donnelly JH Jr, Skinner SJ (1990) Customer participation in service production and delivery. J Retail 66(3):315-335. https://doi.org/10.4135/9781452231327.n10

Kelley SW, Skinner SJ, Donnelly JH Jr (1992) Organizational socialization of service customers. J Serv Res 25(3):197-214. https://doi.org/10.1016/0148-2963(92)90029-B

Kristal T, Yaish M (2020) Does the coronavirus pandemic level the gender inequality curve?(It doesn't). Res Soc Stratif Mobil 68:100520. https://doi.org/10.1016/j.rssm.2020.100520

Kristensson P, Matthing J, Johansson N (2008) Key strategies for the successful involvement of customers in the co-creation of new technology-based services. Int J Serv Ind Manag 19(4):474-491. https://doi.org/10.1108/09564230810891914

Lall RR (2020) Corona-alliances, travel corridors and air bridges: taking a flight is no longer business as usual. https://www.thenationalnews.com/opinion/comment/corona-alliances-travel-corridors-andair-bridges-taking-a-flight-is-no-longer-business-as-usual-1.1034042. Accessed 29 Aug 292021

Lehrer M, Ordanini A, DeFillippi R, Miozzo M (2012) Challenging the orthodoxy of value co-creation theory: a contingent view of coproduction in design-intensive business services. Eur Manag J 30(6):499-509. https://doi.org/10.1016/j.emj.2012.07.006

Lengnick-Hall CA, Claycomb VC, Inks LW (2000) From recipient to contributor: examining customer roles and experienced outcomes. Eur J Mark 34(3/4):359-383. https://doi.org/10.1108/0309056001 0311902

Li Z, Zhang S, Liu X, Kozak M, Wen J (2021) Seeing the invisible hand: underlying effects of COVID-19 on tourists' behavioral patterns. J Dest Mark Manage 18:100502. https://doi.org/10.1016/j.jdmm. 2020.100502

Liao J, Huang M, Xiao B (2017) Promoting continual member participation in firm-hosted online brand communities: an organizational socialization approach. J Bus Res 71:92-101. https://doi.org/10. 1016/j.jbusres.2016.10.013

LiekeDemmers (2016) Co-creating in the hotel industry, the principles and a real-life case on how to approach it. https://www.customerengagementmanagementintourism.wordpress.com/2016/09/ 24/co-creating-in-the-hotel-industry-the-principles-and-a-real-life-case-on-how-to-approach-it. Accessed 20 Aug 2019

Lusch RF, Vargo SL (2006) Service-dominant logic: reactions, reflections and refinements. Mark Theory 6(3):281-288. https://doi.org/10.1177/1470593106066781 
Mathis EF, Kim HL, Uysal M, Sirgy JM, Prebensen NK (2016) The effect of co-creation experience on outcome variable. Ann Tour Res 57:62-75. https://doi.org/10.1016/j.annals.2015.11.023

McIntyre N (1989) The personal meaning of participation: enduring involvement. J Leis Res 21(2):167179. https://doi.org/10.1080/00222216.1989.11969797

Meuter ML, Bitner MJ, Ostrom AL, Brown SW (2005) Choosing among alternative service delivery modes: an investigation of customer trial of self-service technologies. J Mark 69(2):61-83. https:// doi.org/10.1509/jmkg.69.2.61.60759

Neuburger L, Egger R (2021) Travel risk perception and travel behaviour during the COVID-19 pandemic 2020: a case study of the DACH region. Curr Issues Tour 24(7):1003-1016. https://doi.org/ 10.1080/13683500.2020.1803807

Nielsen T, Makransky G, Vang ML, Dammeyer J (2017) How specific is specific self-efficacy? A construct validity study using Rasch measurement models. Stud Educ Evaluation 53:87-97. https://doi. org/10.1016/j.stueduc.2017.04.003

Orazi DC, Bove LL, Lei J (2016) Empowering social change through advertising co-creation: the roles of source disclosure, sympathy and personal involvement. Int J Advert 35(1):149-166. https://doi.org/ 10.1080/02650487.2015.1096101

Park HS, Levine TR, Kingsley Westerman CY, Orfgen T, Foregger S (2007) The effects of argument quality and involvement type on attitude formation and attitude change: a test of dual-process and social judgment predictions. Hum Commun Res 33(1):81-102. https://doi.org/10.1111/j.1468-2958. 2007.00290.x

Pashler H, McDaniel M, Rohrer D, Bjork R (2008) Learning styles: concepts and evidence. Psychol Sci Public Interest 9(3):105-119. https://doi.org/10.1111/j.1539-6053.2009.01038.x

Payne AF, Storbacka K, Frow P (2008) Managing the co-creation of value. J Acad Mark Sci 36(1):83-96. https://doi.org/10.1007/s11747-007-0070-0

Persson-Fischer U, Liu S (2021) The impact of a global crisis on areas and topics of tourism research. Sustainability 13(2):906. https://doi.org/10.3390/su13020906

Petter S, Straub D, Rai A (2007) Specifying formative constructs in information systems research. MIS Q 31(4):623-656. https://doi.org/10.2307/25148814

Podsakoff PM, MacKenzie SB, Lee JY, Podsakoff NP (2003) Common method biases in behavioral research: a critical review of the literature and recommended remedies. J Appl Psychol 88(5):879903. https://doi.org/10.1037/0021-9010.88.5.879

Preacher KJ, Hayes AF (2004) SPSS and SAS procedures for estimating indirect effects in simple mediation models. Behav Res Meth Instrum Comput 36(4):717-731. https://doi.org/10.3758/BF03206553

Prebensen NK, Foss L (2011) Coping and co-creating in tourist experiences. Int J Tour Res 13(1):54-67. https://doi.org/10.1002/jtr.799

Prebensen NK, Vitters $\emptyset$ J, Dahl TI (2013) Value co-creation significance of tourist resources. Ann Tour Res 42:240-261. https://doi.org/10.1016/j.annals.2013.01.012

Rather RA (2021) Monitoring the impacts of tourism-based social media, risk perception and fear on tourist's attitude and revisiting behaviour in the wake of COVID-19 pandemic. Curr Issues Tour. https://doi.org/10.1080/13683500.2021.1884666

Reichers AE (1987) An interactionist perspective on newcomer socialization rates. Acad Manage Rev 12:278-287. https://doi.org/10.5465/amr.1987.4307838

Rollag K (2012) Socializing the "other" organizational newcomers-customers, clients. In: Wanberg C (ed) The oxford handbook of organizational socialization. Oxford University Press, Oxford, pp 250-263

Roth WM (2019) Transactional psychology of education: toward a strong version of the social, vol 9. Springer, Cham

Saks AM, Uggerslev KL, Fassina NE (2007) Socialization tactics and newcomer adjustment: a meta-analytic review and test of a model. J Vocat Behav 70(3):413-446. https://doi.org/10.1016/j.jvb.2006. 12.004

Santos-Vijande ML, López-Sánchez JÁ, Pascual-Fernandez P (2015) Co-creation with clients of hotel services: the moderating role of top management support. Curr Issues Tour 21(3):301-327. https:// doi.org/10.1080/13683500.2015.1078781

See-To EW, Ho KK (2014) Value co-creation and purchase intention in social network sites: the role of electronic Word-of-Mouth and trust-A theoretical analysis. Comput Hum Behav 31:182-189. https://doi.org/10.1016/j.chb.2013.10.013

Sharma P (2021) Customer co-creation, COVID-19 and sustainable service outcomes. Benchmarking 28(7):2232-2258. https://doi.org/10.1108/BIJ-10-2020-0541 
Si SX, Cullen JB (1998) Response categories and potential cultural bias: effects of an explicit middle point in cross-cultural surveys. Int J Organ Anal 6(3):218-230. https://doi.org/10.1108/eb028885

Silvia PJ (2006) Exploring the psychology of interest. Oxford University Press, Oxford

Solomon MR, Surprenant C, Czepiel JA, Gutman EG (1985) A role theory perspective on dyadic interactions: the service encounter. J Mark 49(1):99-111. https://doi.org/10.1177/002224298504900110

Su CJ, Lebrun AM, Bouchet P, Wang JR, Lorgnier N, Yang JH (2016) Tourists' participation and preference-related belief in co-creating value of experience: a nature-based perspective. Serv Bus 10(4):823-846. https://doi.org/10.1007/s11628-015-0292-z

Sugathan P, Ranjan KR (2019) Co-creating the tourism experience. J Bus Res 100:207-217. https://doi. org/10.1016/j.jbusres.2019.03.032

Tan SK, Luh DB, Kung SF (2014) A taxonomy of creative tourists in creative tourism. Tour Manag 42:248-259. https://doi.org/10.1016/j.tourman.2013.11.008

Torkington S (2021) The pandemic has changed consumer behavior forever-and online shopping looks set to stay. Retrieved from https://www.weforum.org/agenda/2021/07/global-consumer-behaviourtrends-online-shopping/. Accessed 29 Aug 2021

Tseng FM, Chiang LL (2016) Why does customer co-creation improve new travel product performance? J Bus Res 69(6):2309-2317. https://doi.org/10.1016/j.jbusres.2015.12.047

UNWTO (2020) International tourist numbers could fall 60-80\% in 2020, UNWTO reports. https://www. unwto.org/news/covid-19-international-touristnumbers-could-fall-60-80-in-2020. Accessed 18 Aug 2021

Van Maanen JE, Schein EH (1979) Toward a theory of organizational socialization. Res Organ Behav 1:209-264

Vargo SL, Lusch RF (2004) Evolving to a new dominant logic for marketing. J Mark 68(1):1-17. https:// doi.org/10.1509/jmkg.68.1.1.24036

Vargo SL, Maglio PP, Akaka MA (2008) On value and value co-creation: a service systems and service logic perspective. Eur Manag J 26(3):145-152. https://doi.org/10.1016/j.emj.2008.04.003

Vroom VH (1964) Work and motivation, vol 54. Wiley, New York

Willingham DT, Hughes EM, Dobolyi DG (2015) The scientific status of learning styles theories. Teach Psychol 42(3):266-271. https://doi.org/10.1177/0098628315589505

Wu CH (2011) A re-examination of the antecedents and impact of customer participation in service. Serv Ind J 31(6):863-876. https://doi.org/10.1080/02642060902960768

Yim CK, Chan KW, Lam SS (2012) Do customers and employees enjoy service participation? Synergistic effects of self-and other-efficacy. J Mark 76(6):121-140. https://doi.org/10.1509/jm.11.0205

Yin J, Ni Y (2021) COVID-19 event strength, psychological safety, and avoidance coping behaviors for employees in the tourism industry. J Hosp Tour Manag 47:431-442. https://doi.org/10.1016/j.jhtm. 2021.04.017

Zaichkowsky JL (1985) Measuring the involvement construct. J Consum Res 12(3):341-352. https://doi. org/10.1086/208520

Zaichkowsky JL (1994) The personal involvement inventory: reduction, revision, and application to advertising. J Advert 23(4):59-70. https://doi.org/10.1080/00913367.1943.10673459

Publisher's Note Springer Nature remains neutral with regard to jurisdictional claims in published maps and institutional affiliations. 